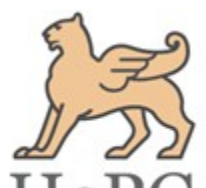

\title{
Ethnobotanical information on some aquatic plants of South 24 Parganas, West Bengal
}

\author{
Rudrajit Chakraborty ${ }^{1}$, M. S. Mondal ${ }^{2}$ and Sobhan Kr. Mukherjee ${ }^{1}$ \\ ${ }^{1}$ Taxonomy and Biosystematics Laboratory, Department of Botany, University of Kalyani, Kalyani, Nadia-741 235. W.B., India. \\ ${ }^{2}$ Central National Herbarium, BSI, Indian Botanic Garden, Howrah, West Bengal.
}

\section{Article history}

Received: 28 March 2016

Accepted: 2 April 2016

Published: 6 April 2016

(C) Chakraborty et al (2016)

Editor

K. K. Sabu

Publisher

Horizon e-Publishing Group

Corresponding Author

Sobhan Kumar Mukherjee

$\bigotimes_{\text {sobhankr@gmail.com }}$

\begin{abstract}
District South 24-Parganas is surrounded by river Hoogly (Ganga) in the West, North 24 Parganas and Bangladesh in the East, the North 24- Parganas and Kolkata in the North and extended up to the fringes of Sundarbans approaching the Mangrove reserves towards Bay of Bengal. Quite naturally the district has an interesting combination of its people and at the same time its floristic composition. In course of the survey of Aquatic Flora of South 24- Parganas, West Bengal, the first authors had collected information regarding traditional use of some plants South 24- Parganas for the treatment of the common ailments; interacting with the local people particularly the ethnic people like Santals and some displaced families from Bangladesh and others. In the present paper, some commonly useable aquatic plants from different families have been enlisted with botanical name, traditional uses including ethno - veterinary application etc.
\end{abstract}

\section{Keywords}

Ethnobotany; Ethnomedicine; Aquatic plants; 24 Parganas(S); W.B.

Chakraborty, R., M. S. Mondal, S. K. Mukherjee. 2016. Ethnobotanical information on some aquatic plants of South 24 Parganas, West Bengal. Plant Science Today 3(2): 109-114. http://dx.doi.org/10.14719/pst.2016.3.2.224

\section{Introduction}

District South 24-Parganas is surrounded by river Ganga (commonly known as Hoogly River) in the West, North 24 Parganas and Bangladesh in the East, the North 24-Parganas and Kolkata in the North and extended up to the fringes of Sundarbans approaching the Mangrove reserves towards Bay of Bengal. Quite naturally the district has an interesting combination of its people and at the same time its people and at the same time its floristic composition. Majority of the plants are typically terrestrial in comparison to the amphibious and hydrophytic ones. At one extreme there are xerophytes - which can withstand by periods of drought and flourish in minimal supply of water, and at the other are the hydrophytes - the water plants. Most aquatic plants inhabit freshwater and swamps - the water may be stagnant or running, whereas a small group inhabit marine conditions. They are either free-floating individuals or rooted with emergent, leafy and reproductive shoots, whereas still others are completely submerged.

It is very difficult to define 'aquatic' plants exactly because aquatic habitats cannot be sharply distinguished from terrestrial ones (Sculthorpe, 1967). According to Muenschar (1944) hydrophytes are those species 'which normally stand in water and must grow for at least a part of their life cycle in water, either completely submerged or immersed'.

Phytosociological studies provide details on the composition, structure, species density and growth, trends of succession and characteristics of community. 


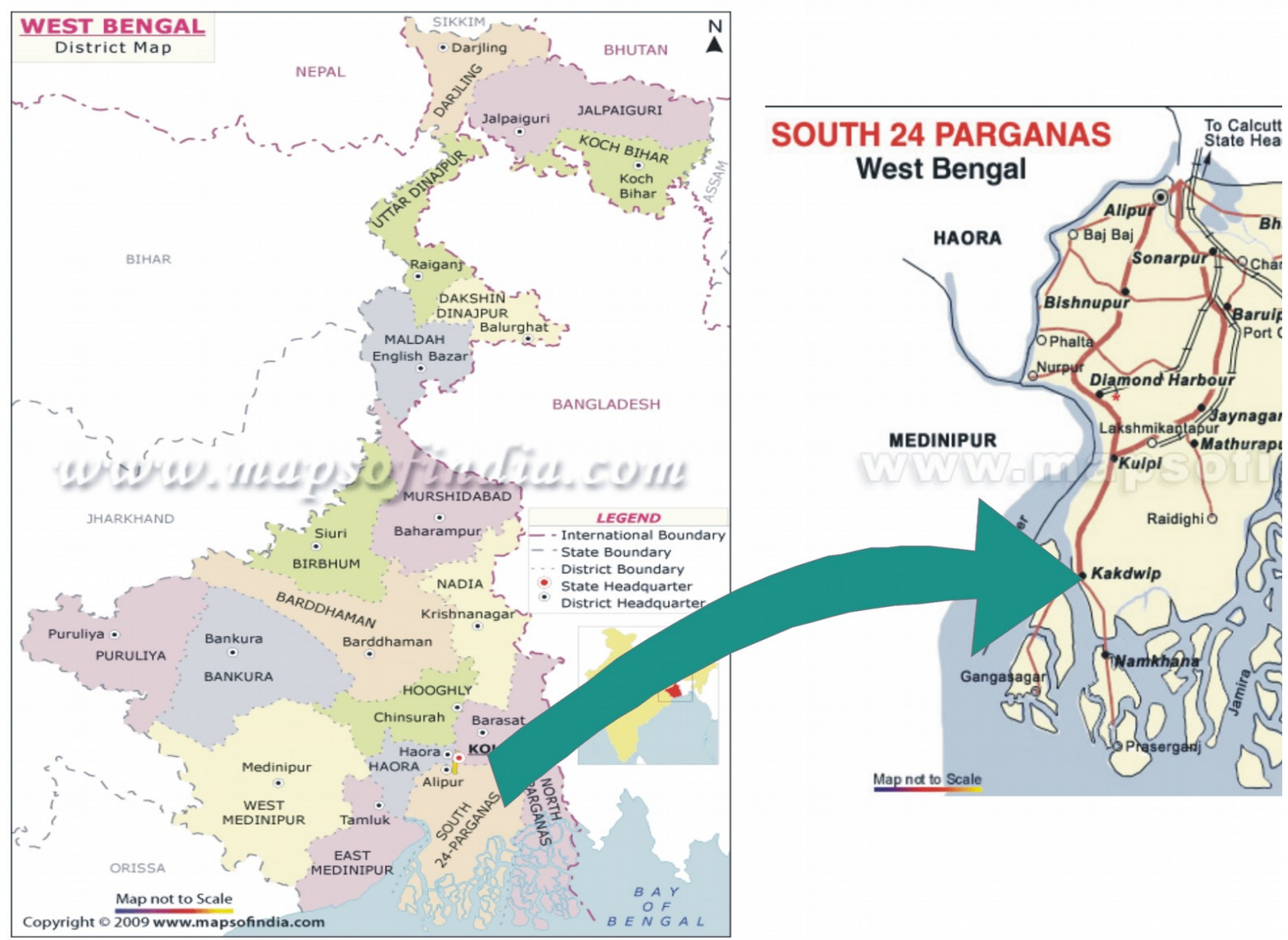

Figure 1: Map of West Bengal and 24 Parganas South

Table 1: Geographical location of the district of South 24 Parganas.

\begin{tabular}{|c|c|c|c|c|c|c|c|}
\hline \multirow{2}{*}{$\begin{array}{l}\text { Name of the } \\
\text { District }\end{array}$} & \multicolumn{2}{|c|}{ Lat. } & \multicolumn{2}{|c|}{ Long. } & \multirow{2}{*}{$\begin{array}{l}\text { Distr. Head } \\
\text { Quarter }\end{array}$} & \multirow{2}{*}{$\begin{array}{c}\text { Lat. } \\
\mathrm{N}\end{array}$} & \multirow{2}{*}{$\frac{\text { Long }}{\mathrm{E}}$} \\
\hline & $\mathbf{N}$ & $\mathbf{S}$ & $\mathbf{E}$ & W & & & \\
\hline $\begin{array}{l}\text { South } 24 \\
\text { Pargana }\end{array}$ & $22^{\circ} 33^{\prime} 45^{\prime \prime}$ & $21^{\circ} 29^{\prime}$ & $89^{\circ} 4^{\prime} 50 "$ & $88^{\circ} 3^{\prime} 45^{\prime \prime}$ & Alipore & $22^{\circ} 32^{\prime}$ & $8^{\circ} 2^{\prime}$ \\
\hline
\end{tabular}

Source: Director, National Atlas, Govt. of India

Table 2: Monthly rainfall in the district South 24 Parganas

\begin{tabular}{|c|c|c|c|c|c|c|}
\hline \multirow[t]{2}{*}{ Month } & \multirow[t]{2}{*}{ Normal (mm) } & \multicolumn{5}{|c|}{ Actual (mm) } \\
\hline & & 2008 & 2009 & 2010 & 2011 & 2012 \\
\hline January & 12 & 0 & 8 & 0 & 27 & 0 \\
\hline February & 19 & 0 & 54 & 1 & 0 & 17 \\
\hline March & 38 & 0 & 0 & 27 & 21 & 35 \\
\hline April & 53 & 1 & 64 & 51 & 51 & 20 \\
\hline May & 139 & 240 & 204 & 107 & 107 & 125 \\
\hline June & 267 & 221 & 275 & 368 & 368 & 368 \\
\hline July & 348 & 411 & 471 & 210 & 210 & 308 \\
\hline August & 202 & 557 & 207 & 374 & 374 & 256 \\
\hline September & 282 & 653 & 258 & 219 & 219 & 172 \\
\hline October & 166 & 232 & 102 & 91 & 91 & 410 \\
\hline November & 57 & 0 & 2 & 84 & 84 & 11 \\
\hline December & 14 & 0 & 0 & 0 & 0 & 32 \\
\hline Total & 1597 & 2315 & 1645 & 1792 & 1552 & 1754 \\
\hline
\end{tabular}

Source: Meteorological Department, Govt. of India

The works of Merlee and Avita (1989); Sheela and Hema (2004) and Sheela and Asha (2007) clearly bring out the importance of phytosociological studies in the present century. Rather than concentrating on floral characters, the study of different taxa in relation to their ethnobotanical use is also gaining momentum. So in this paper, some commonly useable aquatic plants from different families of South 24 Parganas have been enlisted with botanical name, local or vernacular 
Table 3: List of aquatic plants with ethnomedicinal importance

\begin{tabular}{|c|c|c|c|}
\hline Name & Family & Plant parts & Etnomedicinal use \\
\hline 1. Polygonum glabrum Willd. & Polygonaceae & Leaf & Wounds, Colic pain \\
\hline 2. Polygonum. barbatum L. & Polygonaceae & Seed & Colic pain \\
\hline 3. Polygonum. orientale L. & Polygonaceae & Leaf & Wounds, good tonic \\
\hline \multirow[t]{4}{*}{ 4. Ipomoea aquatica Forssk. } & Convolvulaceae & Leaf & On snake bite \\
\hline & & Stem & Poisonous snake bite (pain) \\
\hline & & Tender shoot & Purgative \\
\hline & & Whole plant & Spasmolytic \\
\hline \multirow[t]{2}{*}{ 5. Limnophila indica Druc. } & Scrophulariaceae & Whole plant & Antiseptic, Elephantiasis, Fever, \\
\hline & & & Dysentery \\
\hline \multirow[t]{3}{*}{ 6. Nelumbo nucifera Gaerth. } & Nymphaeceae & Flower & Cardiac tonic for fever and disease of liver. \\
\hline & & Seeds & Cooling medium for skin diseases \\
\hline & & Rhizome & Piles \\
\hline \multirow[t]{2}{*}{ 7. Nymphaea stellata Willd. } & Nymphaeceae & Root & Dyspepsia, Diarrhoea, Piles \\
\hline & & Flower & Heart palpitition \\
\hline 8. Neptunia oleracea Lour. & Mimosaceae & Whole plant & Astringent and cooling agent \\
\hline 9. Hygroryza aristata Nees. & Poaceae & Seeds & $\begin{array}{l}\text { Cooling agent and astringent to urinary tract, } \\
\text { uses in biliousness }\end{array}$ \\
\hline 10. Ceratophyllum demersum L. & Ceratophyllaceae & Whole plant & $\begin{array}{l}\text { Cooling agent, uses in biliousness, Scorpion } \\
\text { sting. }\end{array}$ \\
\hline 11. Vallisneria spiralis L. & Hydrocharitaceae & Leaf & Stomach pain, Leucorrhoea \\
\hline $\begin{array}{l}\text { 12. Monochoria hastata (L.) } \\
\text { Solms. }\end{array}$ & Pontederiaceae & Leaf & Used as tonic, cooling agent for Curing boils. \\
\hline 13. Monochoria vaginalis Presl. & Pontederiaceae & Root & Toothache, Asthma \\
\hline $\begin{array}{l}\text { 14. Typha angustata Chaub \& } \\
\text { Bory. }\end{array}$ & Typhaceae & Root & Astringent and Diuretic \\
\hline 15. Cyperus articulatus L. & Сyperaceae & Tuber & Tonic and Stimulant \\
\hline 16. Scirpus grosus L.f. & Cyperaceae & Tuber & Diarrhoea and Vomiting \\
\hline 17. Jussiaea repens L. & Onagraceae & Whole plant & Skin disease, Ulcer \\
\hline $\begin{array}{l}\text { 18. Nymphoides indica (L.) } \\
\text { Kuntz. }\end{array}$ & Gentianaceae & Whole plant & $\begin{array}{l}\text { The plant is used an substitute for chiratta in } \\
\text { fevers and jaundice }\end{array}$ \\
\hline 19. Hydrolea zeylanica (L.) Vahl. & Hydrophyllaceae & Leaf & Antiseptic, Ulcer \\
\hline
\end{tabular}

Data were gathered randomly from literature and personal interviews

name, locality, traditional uses including ethno veterinary application etc.

\section{Materials and Methods}

An ethnobotanical survey was undertaken to collect information from traditional healers on the use of aquatic medicinal plants in South 24 parganas district of West Bengal. The indigenous knowledge of local traditional healers [Santals and some displaced families from Bangladesh] and the native aquatic plants used for medicinal purposes were collected through questionnaire and personal interviews during field trips. This study showed that many people in the studied area of South 24 Parganas district still continue to depend on medicinal plants at least for the treatment of primary healthcare. Plants were identified with the help of some local floras (Cook, 1990, 1996; Naskar, 1986, 1990; Prain, 1905; Samanta and Das, 2003; Shankar and Mishra, 2012). 


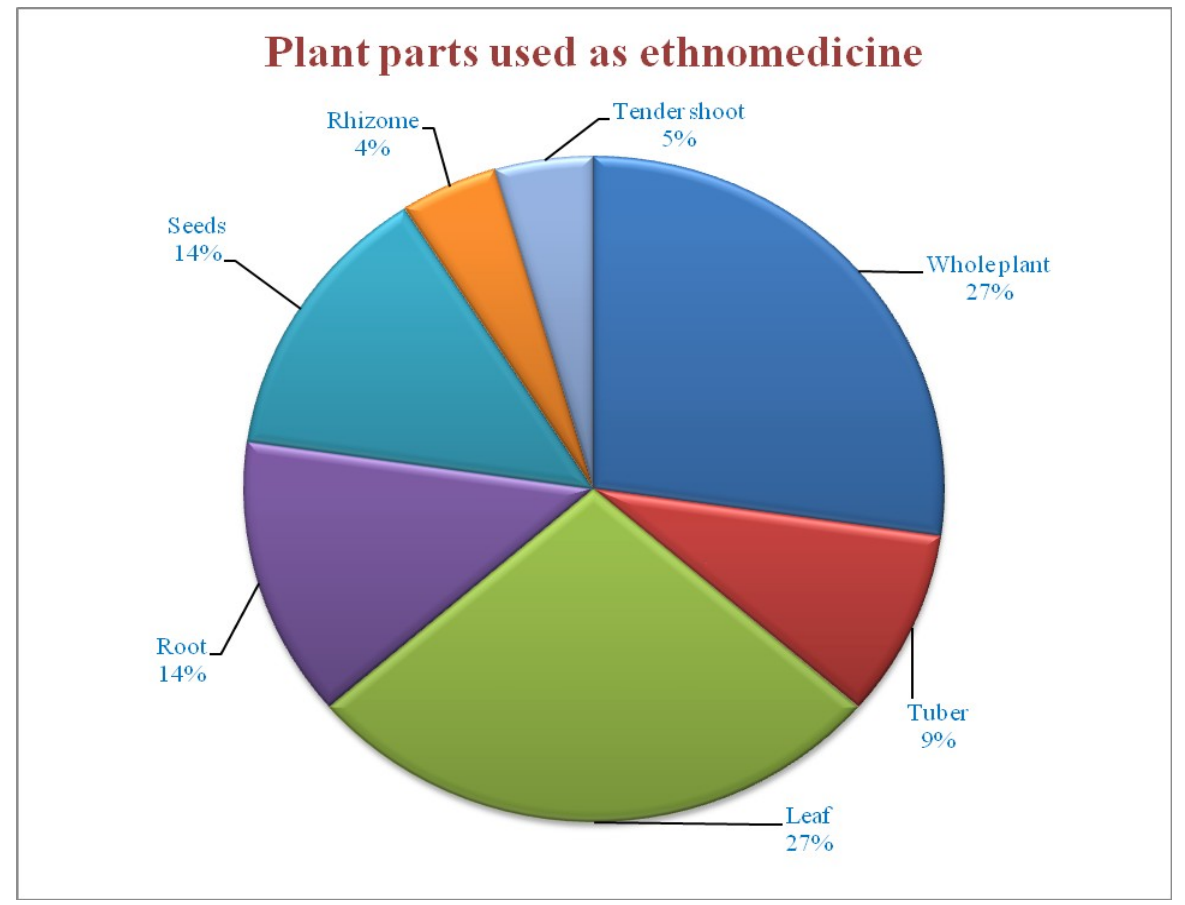

Figure 2: Conspectus of Plant Parts used for treating ailments

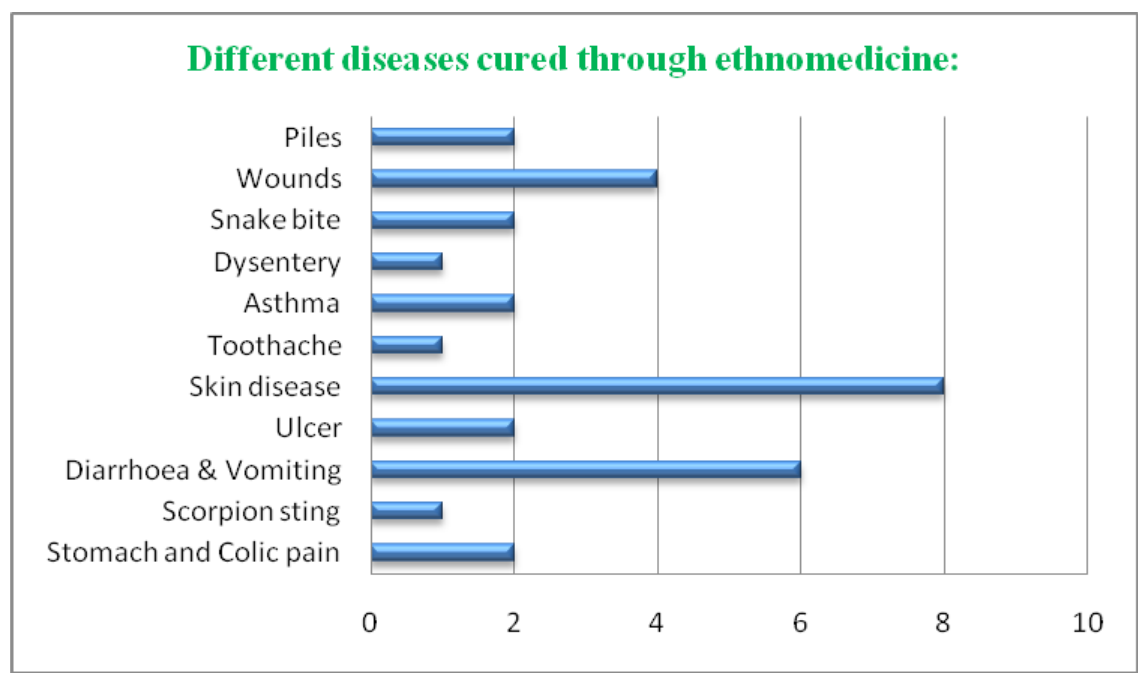

Figure 3: Different diseases cured through ethnomedicine

\section{Study area}

The district is bounded by the latitudes $22^{\circ} 33^{\prime} 45^{\prime \prime}$ $\mathrm{N}$ and $21^{\circ} 29^{\prime} 00^{\prime \prime} \mathrm{N}$ and longitudes $89^{\circ} 4^{\prime} 50^{\prime \prime} \mathrm{E}$ and $88^{\circ} 3^{\prime} 45^{\prime \prime} \mathrm{E}$. The total geographical area of the district in 9960 sq. $\mathrm{km}$. It has 5 Sub-divisions consisting of 29 Block, 29 Panchayat Samities and 26 Police Stations. There are 312 Gram Panchayats with 4324 villages. Alipore is the headquarters of the district. The district is located in the mature tract of Gangetic delta in Lower Ganga basin. Hugli, Matla, Bidyadhari, Raimangal, Saptamukhi rivers with their tributaries/distributaries form the main drainage in this district (Figure 1; Table 1).

\section{Climate}

The district is characterized by hot and humid climate. It receives adequate rainfall from NorthEast and South-West monsoons which set in the later half of June and withdraw by the middle of October. Pre-monsoon rains are received during March-April.

\section{Temperature}

The climate of South 24 Parganas is monsoonal type. The annual range of temperature varies from $13^{\circ} \mathrm{C}$ to $40^{\circ} \mathrm{C}$. May is the hottest month with temperature as high as $40^{\circ} \mathrm{C}$ and January is the coldest month with temperature as low as $10^{\circ} \mathrm{C}$.

\section{Rainfall}

The normal annual rainfall in this district is of the tune of $1800 \mathrm{~mm}$. Lower littoral part receives high rainfall which gradually decreases towards the northwest (Table 2). 
Table 4: List of aquatic plants with other ethnobotanical uses

\begin{tabular}{lll}
\hline Name & Family & Ethobotanical uses \\
\hline Nelumbo nucifera Gaertn. & Nelumbonaceae & $\begin{array}{l}\text { It is National flowers and is treated as a sacred flower. Hindus } \\
\text { offer it in many religious occasions. Flowers are used in Hindu } \\
\text { and Buddhist temples for the worship and religious purposes. }\end{array}$ \\
& $\begin{array}{l}\text { Pickles prepared from the petioles. The leaves are occasionally } \\
\text { used as food plates. Rhizomes, seeds, leaves are occasionally } \\
\text { used as vegetable. }\end{array}$ \\
\hline
\end{tabular}

\begin{tabular}{|c|c|c|}
\hline Neptunia oleracea Lour. & Mimosaceae & Young shoot of the plant is used as pot herb. \\
\hline \multirow[t]{4}{*}{$\begin{array}{l}\text { Ceratophyllum } \\
\text { demersum L. }\end{array}$} & Ceratophyllaceae & The plant is a good fodder and rich in protein. \\
\hline & & Grass carp relishes the plants. \\
\hline & & Fried plant is also good manure \\
\hline & & Good oxygen producer and used as decorative aquarium plant \\
\hline $\begin{array}{l}\text { Monochoria hastata (L.) } \\
\text { Solms }\end{array}$ & Pontederiaceae & $\begin{array}{l}\text { Tender stalk and leaves are eaten as vegetable. Rootstocks are } \\
\text { used as food for cattle and pigs. }\end{array}$ \\
\hline $\begin{array}{l}\text { Nymphoides indica (L.) } \\
\text { Kuntze }\end{array}$ & Menyanthaceea & Plants are eaten as vegetable. Plants are eaten as vegetable. \\
\hline Vallisneria spiralis L. & Hydrocharitaceae & $\begin{array}{l}\text { Young leaves eaten as salads. Largely it is used in domestic } \\
\text { aquaria and it has great capacity in purifying water, so fish } \\
\text { culture is helped directly or indirectly. }\end{array}$ \\
\hline
\end{tabular}

Data were gathered randomly from literature \& personal interviews

\section{Soil}

The district has three types of soils-

I. Younger alluvial soil: The Younger alluvial is predominant in the northern and eastern parts of the district, being mainly characterized by flood plains of numbers of small rivers in the deltaic part.

II. Coastal alluvial soil: The coastal alluvial soil is mainly observed in the southern part of the district.

III. Saline and saline alkali: The extreme southern margin of the district is covered with saline and saline alkali soil of coastal origin.

\section{Results and Discussion}

The investigation revealed that, the traditional healers used 19 species of plants distributed in 16 genera belonging to 14 families to treat various diseases (Table 3,4). The documented medicinal plants were mostly used to cure skin diseases, poison bites, stomachache, ulcer, dysentery, diarrhoea and piles. In this study the most dominant family was Polygonaceae. The study also shows that the leaves (27\%) and whole plant (27\%) were most frequently used for the treatment of different types of diseases. The next important part of the plants were used to treat different diseases as follows: Roots (14\%), Seeds (14\%), Tubers (9\%), Tender shoots (5\%), and Rhizome (4\%) (Figure 2).
According to the local people, ojhas, and rural health workers as many as $60 \%$ of the district's people depend on traditional medicine for their primary healthcare needs. Due to less communication means, poverty, and unavailability of modern health facilities, most people especially rural people are still forced to practice traditional medicines for their common ailments. This study also shows that tribal populace have been used the aquatic plants of this district in mainly for the treatment of skin diseases, diarrhoea and vomiting and also for the wounds along with some other diseases like poison bites, stomachache, ulcer, asthma, toothache and piles (Figure 3).

\section{Conclusion}

This study showed that many people in the studied areas of South 24 Parganas district still continue to depend on local medicinal plants at least for the treatment of primary healthcare and some of which are of aquatic origin.

\section{Acknowledgements}

First author is expressing his gratitude to the informants of the South 24 Parganas district for their cooperation and kind help. He is very much thankful to his friend, Mr. Bidyut Kumar Jana of Department of Botany, University of Kalyani for his co-operation and help. Third author is thankful to the DST - Purse of the University of Kalyani for financial support to work this topic. 


\section{References}

Cook, C.D.K. 1990. Aquatic Plant Book. SPB Academic Press, Hague, Netherland.

Cook, C.D.K. 1996. Aquatic and Wetland Plants of India. Oxford University Press, New Delhi, India.

Merlee, T.M.V. \& Avita, Sr. 1989. Autecological studies on Indian senega (Polygala chinensis) - a medicinal plant. Feddes Repart. 100. 157-165. doi: 10.1002/fedr.4911000312

Muenscher, W.C. 1944. Aquatic Plants of the United States. Ithaoa, New York, Comstock Publishing Co.

Naskar, K.R. 1986. Recent trends of aquatic weeds management through proper utilization. Pl. Sci. Res. (Visvabharati), pp. 188-193.

Naskar, K.R. 1990. Aquatic and Semi-Aquatic Plants of the Lower Gangetic Delta. Daya Publishing House, New Delhi, India.

Prain, D. 1905. The vegetation of the districts of HugliHowrah and 24-Parganas. Rec. Bot. Surv. India 3(2): 143-329.
Samanta, A.K. and D.C. Das, 2003. Ethnobotanical studies on Typha elephantina Roxb. (Typhaceae) in the southern parts of West Bengal, India. J. Econ. Taxon. Bot. 27(3): 576 -579.

Sculthrope, C.D. 1967. Biology of Aquatic Vascular Plants. London .

Shankar, L.H. and P.K. Mishra, 2012. Study of aquatic medicinal plants of Hazaribagh district of Jharkhand, India. I.R.J.P. 3(4): 405-409.

Sheela, D. and G. Asha, 2007. Ecological studies on three medicinally important plants of the family Compositae. Nature, Environment and Pollution Technology 6: 515-520.

Sheela, D. and S. Hema, 2004. Phytosociological studies on Eleutheranthera ruderalis (Sw.) Sch.-Bip. - An exotic weed in Kerala. Geobios 30: 271-273. 